\title{
Profil Dan Sensitivitas Protein Alergen Ikan Tongkol (Thunnus albacares) Sebagai Reagen Skin Prick Test (SPT)
}

\section{Profile and Sensitivity of Protein Allergens of Tuna Fish (Thunnus albacares) As a Skin Prick Test (SPT) Reagent}

\author{
Sri Yadial Chalid ${ }^{1 *}$, Dahrul Syah ${ }^{2}$, Puspo Edi Giriwono ${ }^{2}$, Fransiska Rungkat $^{2}$, Zakaria $^{2}$ \\ ${ }^{1}$ Program Studi Kimia, Fakutas Sains dan Teknologi, Universitas Islam Negeri Syarif Hidayatullah Jakarta \\ Jl. Ir. H. Djuanda No. 95. Ciputat, Tangerang Selatan 15412, Indonesia \\ ${ }^{2}$ Departemen Ilmu dan Teknologi Pangan, Fakultas Teknologi Pertanian, Institut Pertanian Bogor \\ Jl. Lingkar Akademik, Kampus IPB Darmaga, Bogor 16680, Indonesia \\ *Corresponding author: sri.yadial@uinjkt.ac.id
}

Received: June 2018; Revision: December 2018; Accepted: March 2019; Available online: May 2019

\begin{abstract}
Abstrak
Ikan tongkol merupakan salah satu produk laut penyebab alergi makanan. Gejala klinis reaksi alergi makanan adalah gatal, bentol, bengkak, sesak nafas, batuk, dan yang terparah adalah syok anafilaksis. Pengobatan dan pencegahan alergi makanan yang terbaik adalah menghindari konsumsi penyebab alergi. Menghindari konsumsi suatu makanan sebaiknya berdasarkan uji alergi seperti Skin Prick Test (SPT). SPT dilakukan menggunakan reagen SPT yang dicukitkan pada lapisan epidermis kulit lengan bagian volar. Reagen alergen pada penelitian ini merupakan protein ikan tongkol yang berasal dari laut Indonesia dan diekstrak dengan buffer fosfat, Profil ekstrak protein menggunakan elektroforesis dan immunoblotting untuk menentukan protein allergen. Sebanyak 15 pita protein terdeteksi pada ekstrak ikan tongkol yaitu protein dengan berat molekul antara 17 sampai 152 $\mathrm{kDa}$. Potensi alergenik terdapat pada pita protein dengan berat molekul antara 12 sampai $50 \mathrm{kDa}$. Reagen SPT ikan tongkol mempunyai sensitivitas sebesar $81.8 \%$ dan spesifitas $100 \%$ sehingga disimpulkan bahwa reagen ekstrak ikan tongkol dapat digunakan sebagai reagen skin prick test
\end{abstract}

Kata kunci: Alergi, protein, tongkol, gejala klinis, skin prick test

\begin{abstract}
Tuna fish is one of the marine products that can cause allergic. Clinical symptoms of allergic are a bump, swelling, shortness of breath, coughing and anaphylactic shock is the worst symptom. The best medication and treatment is avoiding the consumption of food that could cause allergy. Avoiding consumption of food should be based on an allergy test such as a Skin Prick Test (SPT). SPT using reagent which is applied on the skin of the forearm between the wrist and elbow. The reagent for SPT is a protein solution of tuna which was extracted by phosphate buffer then protein profile was detected using electrophoresis. Immunoblotting was done to determine the molecular weight of the allergen protein. Fifteen protein bands were detected on tuna fish extract; the molecular weight of the protein was obtained between 17 to $152 \mathrm{kDa}$. Protein allergenic are molecules that have protein bands with a molecular weight between 12 and $50 \mathrm{kDa}$. Tuna fish extract solution for SPT had a sensitivity is $81.8 \%$, and specificity is $100 \%$, it was concluded that tuna fish reagent could be used as SPT reagent.
\end{abstract}

Keywords: Allergen, protein, tuna fish, skin prick test.

DOI: $10.15408 / j k v . v 5 v 1.9678$

\section{PENDAhuluan}

Alergi makanan merupakan respon abnormal sistem imun tubuh terhadap komponen bahan makanan terutama protein dan glikoprotein. Reaksi alergi makanan ditandai dengan gelaja klinik yang kompleks yaitu eritema, gatal-gatal pada permukaan tubuh dan mulut, kejang perut, asma dan syok 
anafilaksis (Kindt et al., 2007; Valenta et al., 2015.

Menurut Cianferoni dan Spergel (2009) prevalensi alergi makanan di negara Barat lebih tinggi terjadi pada anak-anak sebesar $8 \%$ sedangkan dewasa hanya $2 \%$. Jumlah penderita alergi makanan di Indonesia belum tercatat dengan baik namun informasi kasus alergi makanan dilaporkan oleh Baratawidjaja (1991) dimana prevalensi alergi makanan sekitar 5-11\%. Chandra et al., (2011) juga melaporkan bahwa udang penyebab alergi pada anak-anak sebesar $8.8 \%$ dan orang dewasa sebesar $24.3 \%$.

Cara terbaik untuk mencegah dan mengobati alergi makanan adalah menghindari penyebab dan pencetus alergi (Durham dan Church 2006). Menghindari konsumsi suatu makanan harus ditegakkan berdasarkan tes alergi seperti immunoterapi (Nurmatov et al., 2017), DBPCFC (double-blind, placebocontrolled food challenge) dan skin prick test Kombinasi SPT dengan uji provokasi makanan memberikan hasil yang akurat (Lubis et al., 2017).

SPT cara untuk mengkofirmasi penyakit alergi obat dan makanan dengan menggunakan ekstrak allergen (Heinzerling et al., 2013). Menurut Kianifar et al., 2016) merupakan uji allergi makanan yang SPT mempunyai akurasi tinggi yaitu $65 \%$ positif untuk pasien yang ditantang (chalange) dengan susu sapi, telur, kacang tanah dan ikan.

Bahan utama pada SPT adalah reagen alergen yaitu protein alergen yang disebut dengan reagen. Reagen SPT harus distandarisasi menurut European Academy of Allergy and Clinical Immunology manual yang meliputi kadar protein, kadar air, profile protein, mikrobiologi, uji pada penderita alergi makanan dan non alergi dan immunoblotting.

Mekanisme reaksi alergi makanan terjadi melalui reaksi hipersensitivitas yang dimediasi oleh immunoglobulin $\mathrm{E}$ (IgE) melalui fase sensitasi, fase aktivasi dan fase efektor. Fase sensitasi diawali dengan rangsangan terhadap sel B oleh alergen yang memicu produksi IgE. Secara spesifik IgE berikatan dengan reseptor permukaan (Fce-R) sel mastosit dan basofil dan dapat bertahan sampai berbulan bulan. Fase sensitasi dapat terjadi sejak masa kandungan, kanak-kanak dan dewasa (Rabson et al., 2005; Kindt et al., 2007). Sel yang tersensitasit bertahan bertahun-tahun tanpa kontak ulang dan bersifat sebagai memori imunogenik (Cynthia dan Malcolm 2008).

Fase kedua adalah fase aktivasi yaitu paparan kedua dengan alergen yang sama dan membentuk ikatan silang antara alergen dengan dua molekul IgE pada sel mastosit dan basofil. Afinitas ikatan silang ini menyebabkan aktivasi sel sehingga melepaskan beberapa mediator sel yang bersifat patologik seperti histamin, protease dan leukotrien. Fase selanjutnya disebut dengan fase efektor yaitu fase yang kompleks bersifat patologik. Gelaja klinik yang kompleks dari fase ini ditandai: eritema, gatal-gatal pada permukaan tubuh dan mulut, kejang perut, asma dan syok anafilaksis (Kindt et al., 2007; Valenta et al., 2015).

Penelitian ini bertujuan memproduksi reagen SPT dari bahan lokal Indonesia karena reagen SPT dari makanan yang terstandardisasi masih terbatas jumlahnya, kompleksitas alergen makanan seperti subspesies yang beragam dan tumbuh dan berkembang di berbagai kondisi yang mencerminkan variasi geografis, dan umumnya impor sehingga harga SPT mahal.

Reagen SPT diproduksi sesuai standar

European Pharmacopoeia Monograph on Allergen Products 2010:1063., yang menetapkan parameter kadar protein, sterilitas, profil protein dengan metode Sodium dodcylsulfate polyacrilamine gel electrophoresis (SDS-PAGE), immunobloting untuk menentukan protein alergen dengan menggunakan serum respoden alergi makanan dan non alergi sebagai kontrol. Protokol penelitian ini sudah lolos kaji etik oleh Komisi Etik Penelitian Fakultas Kesehatan Masyarakat, Universitas Diponegoro No.190/EC/FKM/2014.

\section{METODE PENELITIAN Alat dan Bahan}

Bahan utama yang digunakan pada penelitian ini adalah ikan tongkol diperoleh dari nelayan pada Tempat Pelelangan Ikan (TPI) Pelabuhan Ratu Jawa Barat. Ikan tongkol dianalisa kandungan protein, lemak, air dan abu. Zat kimia utama yang digunakan adalah bufer fosfat $\mathrm{pH} 7.5$, coomasie brilliant blue $G$ 250, gliserol-salin, antibodi anti IgE manusia berlabel enzim HRP (Horseradish Peroksidase), substrat DAB (3,3Diaminobenzidine), substrat TMB (3,3',5,5'Tetramethylbenzidine), N,N-metilenbisakrilamid, low molecular weight protein 
(LMW) Fermentas ${ }^{\circledR}$ (mengandung 7 jenis protein standar yaitu $\beta$-galaktosidase (116 $\mathrm{kDa})$, bovine serum albumin (66.2 $\mathrm{kDa})$, ovalbumin $(45 \mathrm{kDa})$, lactate dehidrogenase (35 kDa), RNase BSP 981 (25 kDa), $\beta$ lactoglobulin $(18.4 \mathrm{kDa})$, dan lisozim (14.4 $\mathrm{kDa}$ ). Kadar protein, kadar, lemak, air dan abu sampel diuji mengacu pada metode AOAC (2005)

Skin prick test dan pengambilan darah menggunakan subjek manusia sebanyak 66 orang, berjenis kelamin perempuan dan lakilaki. Sebanyak 58 subjek menderita alergi makanan dan 8 orang non alergi makanan. Umur subjek berkisar antara 18-30 tahun. Subjek berdomisili di Kecamatan Ciputat, tidak menderita sakit panu, kudis, kurap, urtikaria pada kulit. Subjek sudah menanda tangani informed consent.

\section{Ekstraksi Protein}

Sebanyak 1 gram daging ikan tongkol dihomogenisasi dengan larutan bufer fosfat $0.05 \mathrm{M} \mathrm{pH} 7.5$ sebanyak $10 \mathrm{~mL}$ dan $0.02 \mathrm{~mL}$ aprotinin (inhibitor protease) menggunakan blender selama 3 menit. Suspensi ikan tongkol disentrifuse pada kecepatan $5000 \mathrm{x}$ g pada $4{ }^{\circ} \mathrm{C}$ selama 15 menit. Supernatan dikeringkan dengan freeze dryer dan disebut dengan ekstrak protein ikan tongkol (Hashimoto et al., 1979; Diaz-Tenorio et al., 2007; Benjakul et al., 2002).

Kadar histamin ditentukan dengan menggunakan metode HPLC dengan kolom C-18, fase gerak asetonitril, detektor fluoresence dan volume injeksi sebanyak 20 $\mu \mathrm{L}$. Kadar protein terlarut dianalisis dengan menggunakan metode Bradford (1979).

\section{Profil Protein dengan Elektroforesis}

Sebanyak $0.1 \mathrm{~g}$ ekstrak protein ikan tongkol dilarutkan dengan $2 \mathrm{~mL}$ phosphate buffer saline (PBS) dengan bantuan sonikator. Karakterisasi profil protein dengan SDS-PAGE yaitu menggunakan poliakrilamida dengan konsentrasi stacking gel 5\% dan separating gel $12 \%$.

Sebanyak $40 \quad \mu \mathrm{L}$ sampel ekstrak protein ikan tongkol ditambahkan $10 \mu \mathrm{L}$ bufer sampel dipanaskan selama 5 menit dalam air mendidih. Sampel diinjeksikan ke dalam sumur menggunakan mikropipet. Salah satu sumur diinjeksikan protein marker sebanyak 5 $\mu \mathrm{L}$. Alat elektroforesis diset pada tegangan 90 volt selama 150 menit sampai migrasi tersisa sekitar $0.5 \mathrm{~cm}$ dari dasar. Gel diangkat dari slab dan dipindahkan ke dalam wadah tertutup yang telah berisi pewarna coomasie brilliant blue G-250 dan dicuci beberapa kali dengan akudes lalu ditambahlan destaining untuk menghilangkan warna biru. Berat molekul pita protein dihitungan dengan menggunakan software Gel Analyzer 2010a (http://www.gelanalyzer.com/).

\section{Produksi Larutan (Reagen) SPT}

Sebanyak $0.1 \mathrm{~g}$ dilarutkan dengan 2 $\mathrm{mL}$ PBS $\mathrm{pH} 8$ dengan bantuan sonikasi, disentrifus pada kecepatan 11780 rpm selama 15 menit. Supernatan disaring secara bertingkat menggunakan filter $0.45 \mu \mathrm{m}$ dan 0.2 $\mu \mathrm{m}$. Kadar protein terlarut diuji dengan metode Bradford. Konsentrasi larutan SPT ditepatkan menjadi $1 \mu \mathrm{g} / \mu \mathrm{L}$, bila konsentrasi lebih besar dari $1 \mu \mathrm{g} / \mu \mathrm{L}$ maka harus diencerkan dengan $50 \%$ gliserol-salin yang mengandung 0.4 fenol steril.

Sebanyak $1.0 \mathrm{~mL}$ reagen SPT dimasukkan botol vial $5 \mathrm{~mL}$ steril, dikerjakan pada ruang steril. Uji sterilitas dilakukan untuk mengetahui apakah produksi reagen STP steril atau tidak. Uji kadar protein dan kadar air untuk mengetahui apakah reagen SPT sudah memenuhi standar Eropa.

\section{Uji Sterilitas Reagen SPT}

Uji sterilitas pada penelitian ini adalah uji untuk bakteri Pseudomonas aeruginosa, Staphylococcus aureu yaitu bakteri penyebab infeksi pada kulit. Bila hasil uji steril dinyatakan negatif maka reagen bisa dicukitkan pada kulit. Uji sterilitas mengikuti prosedur Farmakope Indonesia edisi IV tahun 1995 menggunakan media yang mengandung tryptic soy agar (TSA) dan diinkubasi selama 2 hari pada suhu $37^{\circ} \mathrm{C}$ dan diamati pertumbuhan bakteri.

\section{Skin Prick Test}

Skin prick test dan pengambilan darah responden dilakukan oleh tenaga medis pada Klinik Alergi dan Asma DR. Indrajana Jakarta dengan mengikuti prosedur standar klinis. Pelaksanaan SPT mengacu pada Maleki et al., (2010) dan Heinzerling et al., (2013). Skin prick test dilakukan pada lengan bawah bagian volar. Lengan harus bersih dengan alcohol $70 \%$ dan biarkan sampai kering. Area yang akan ditetesi alergen ditandai dengan bolpoin.

Histamin dengan konsentrasi $1 \mu \mathrm{g} / \mu \mathrm{L}$ 
digunakan sebagai kontrol positif dan larutan $50 \%$ gliserol-saline sebagai kontrol negative. Kedua larutan ini dicukitkan pada posisi berseberangan kemudian reagen ekstrak ikan tongkol diteteskan dengan konsentrasi $1 \mu \mathrm{g} / \mu \mathrm{L}$. Tetesan pada kulit lengan dicukitkan dengan menggunakan blood lancet dengan perlahan dengan kemiringan $45^{\circ}$ menembus lapisan epidermis tanpa menimbulkan pendarahan.

Hasil cukitan dibaca setelah 20 menit dengan mengukur diameter bentol. Hasil pengukuran dinyatakan 0 bila sama dengan kontrol negatif, positif satu bila ukuran bentol 25-50\% lebih besar dari kontrol negatif (kurang dari $3 \mathrm{~mm}$ ), positf dua bila ukuran bentol 50-75\% lebih besar dari kontrol negatif atau ukurannya 3-5 $\mathrm{mm}$ dan positif tiga bila ukuran bentol sama besar dengan ukuran bentol pada histamine dan positif empat bila ukuran bentol 25-50\% lebih besar dari ukuran histamin dan lebih besar dari +4 bila ukuran bentol lebih 50\% lebih besar dari histamin (Verstege et al., 2005; Heinzerling et al., 2013).

Darah responden diambil dari pembuluh arteri brachialis sebanyak $10 \mathrm{~mL}$, dimasukkan ke dalam tabung glass tube plain 5 $\mathrm{mL}$, didiamkan selama 1 jam, lalu disentrifus dengan kecepatan $1250 \mathrm{rpm}$ dan suhu $4{ }^{\circ} \mathrm{C}$ selama 20 menit (Engbaek et al., (200). Darah yang disentrifus menghasilkan supernatan yang mengandung serum dan endapan mengandung sel darah merah. Supernatan sebanyak $\pm 5 \mathrm{~mL}$ dipipet untuk analisis IgE total, IgE spesifik dan uji immunobloting. Nilai sensitivitas dan selektifitas reagen ikan tongkol dihitung dari hasil SPT, nilai immunoglobulin E (IgE) dan immunoglobulin E-spesifik (IgE spesifik) (Maleki et al., (2010).

\section{Immunobloting}

Gel hasil elektroforesis yang tidak diwarnai ditransfer ke dalam membran polyvinylidene difluoride (PVD) menggunakan alat transblotting selama 1.5 jam dan 90 volt. Membran dilepaskan dan difiksasi dengan metanol $50 \%$ selama 2 menit, ditambahkan larutan susu skim 5\% dalam buffer phosphate saline-tween (PBST), dibiarkan selama 1 jam sambil digoyang. Dicuci dengan PBST sebanyak 3 kali sambil digoyang perlahanlahan. Serum responden yang positif pada SPT diencerkan dengan PBST (1:10), lalu ditambahkan ke dalam membran, diinkubasi selama 24 jam, pada suhu dingin $\left(4{ }^{\circ} \mathrm{C}\right.$. $)$
Membran dicuci dengan PBST selama 5 menit sebanyak 3 kali sambil digoyang, ditambahkan antibodi HRP conjugated monoclonal mouse anti-human IgE, yang telah diencerkan terlebih dahulu dengan PBST (1:3000). HRP merupakan antibodi skunder anti IgE spesifik manusia yang memberikan warna ketika ditambahkan substrat DAB $(3,3$ Diaminobenzidine). Campuran ini diamkan selama 1 jam sambil digoyan-goyang. Tambahkan $10 \mathrm{~mL}$ substrat DAB dan biarkan sampai muncul pita berwarna coklat (Bollag dan Edelstein 1991; Brian et al., 2017).

\section{Uji Sensitivitas dan Spesifitas Reagen Ikan Tongkol}

Sensitivitas merupakan proporsi orang yang benar-benar sakit dalam suatu populasi yang juga diidentifikasi sebagai orang sakit oleh tes skrining (Canoy dan Dexter, 2015), Sensitivitas reagen SPT harus dipenuhi harus dipenuhi (Hansen et al., 2001). Spesifisitas adalah proporsi orang yang benar-benar tidak sakit dan tidak sakit pula saat diidentifikasi dengan tes skrining. Nilai spesifitas menunjukkan seberapa sering tes menghasilkan nilai negatif ketika digunakan pada orang-orang sehat.

Pengukuran sensitifitas dan spesifitas diambil dari data pengujian nilai IgE total dan IgE spesifik dengan menggunakan serum responden yang dibandingkan dengan nilai SPT (data tidak ditampilkan).

\section{HASIL DAN PEMBAHASAN Karakteristik Ikan Tongkol}

Sebanyak 15 gram bagian otot ikan tongkol berwarna merah kehitaman tanpa tulang (Gambar 1) dengan kadar protein $29.58 \%$, lemak $7.08 \%$. air $39.05 \%$, abu $5.84 \%$ Vlieg dan Murray (1988) menyatakan bahwa komposisi kimia dari tongkol albacore ( $T$ alalunga) adalah protein sebesar $25 \%$ dan lemak $4.06 \%$, sedangkan kandungan protein dan lemak pada tongkol Euthynnus affinis segar didaptakan sebesar $24 \%$ dan $14 \%$ masing-masing untuk kadar protein dan lemak Aberoumand (2012).

\section{Kadar Histamin}

Histamin adalah bioamin hasil dekarboksilasi asam amino histidin secara enzimatik. Kadar histamin pada ikan menentukan tingkat kebusukan terutama pada ikan laut. Menurut FDA Codex Alimentarius 
kadar histamin pada ikan dan produk ikan yang masih diizinkan untuk dikonsumsi adalah 200 ppm (Er et al., 2014). kadar histamin yang tinggi menyebabkan keracunan dengan gejala muntah-muntah, rasa terbakar pada kerongkongan, bibir bengkak, sakit kepala, kejang, mual, muka dan leher kemerahan, gatal- gatal pada mulut dan badan (Taylor et al., 1989).

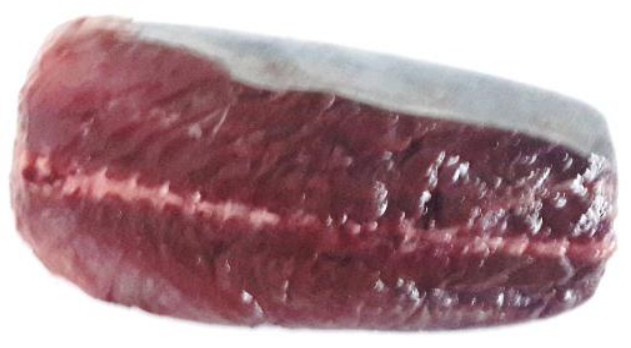

Gambar 1. Bagian daging ikan tongkol

Kadar histamin pada ekstrak protein ikan tongkol pada penelitian ini didapatkan sebesar 0.17 ppm, European Academy of Allergy and Clinical Immunology tidak menentukan batasan kadar histamin pada reagen SPT sehingga sampel yang digunakan pada penelitian ini aman sebagai larutan SPT. Hal ini dapat dipahami karena mekanisme reaksi alergi dengan keracunan histamin berbeda jauh walaupun gejala medis hampir sama.

Keracunan histamin berasal dari makanan yang mengadung histamin sedangkan alergi makanan disebabkan oleh reaksi immnunologik dalam tubuh melalui beberapa fase. Pernyataan ini didukung oleh Rabson et al., 2005 dan Kindt et al., 2007 yaitu reaksi alergi diawali dengan fase sensitasi, fase aktivasi dan fase efektor. Fase sensitasi diawali dengan rangsangan terhadap sel $\mathrm{B}$ oleh alergen pada paparan pertama yang memicu produksi IgE. IgE berikatan dengan reseptor permukaan sel mastosit dan basophil, sel yang tersensitasi bertahan breath tahun dan bersifat sebagai memori imunogenik (Cynthia dan Malcolm, 2008). Alergen yang sama pada paparan kedua berikatan silang dengan dua molekul IgE pada sel mastodit dan basophil. Afinitas ikatan silang ini menyebabkan sel teraktivasi sehingga melepaskan beberapa mediator inflamasi seperti histamin, prostaglandin, leukotrien, heparin dan platelet-activating factor (Kay, 2001) yang bersifat patologik.

\section{Profil Protein Ikan Tongkol dengan SDS- PAGE}

Beberapa parameter yang ditetapkan oleh European Pharmacopoeia Monograph on Allergen Products (2010:1063) adalah kadar air, kadar protein, sterility, alergenisitas dan profil protein. Profil ekstrak protein ikan tongkol hasil SDS-PAGE ditampilkan pada Gambar 2.
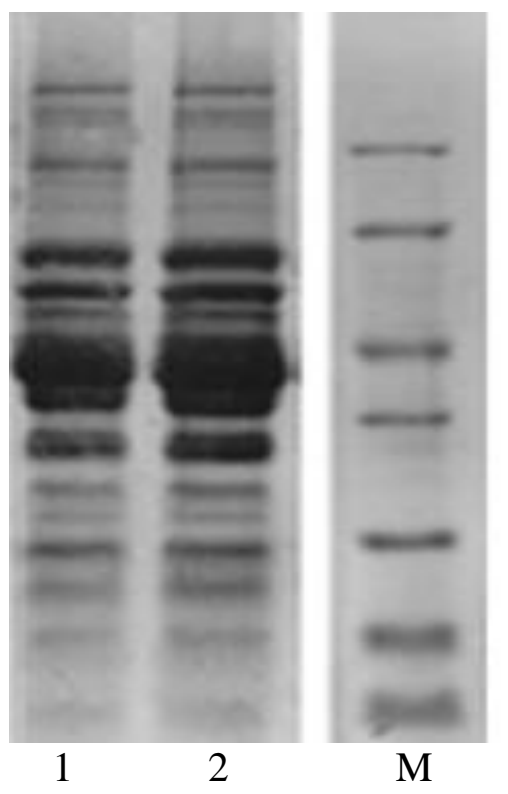

$116 \mathrm{kDa}$

$66,2 \mathrm{kD}$

$45 \mathrm{kDa}$

$35 \mathrm{kDa}$

$25 \mathrm{kDa}$

$18,4 \mathrm{kDa}$

$14,4 \mathrm{kDa}$

Gambar 2. Hasil elektoforesis ekstrak protein ikan tongkol 1,2 dan $\mathrm{M}$ adalah protein marker

Angka 1 dan 2 adalah variasi konsentrasi ekstrak protein ikan tongkol yaitu 15 dan $20 \mu \mathrm{g} / \mathrm{L}$. Berat molekul pita protein SDS-PAGE ditentukan dengan software GelAnayzer 2010a, dan hasilnya ditampilkan pada Tabel 1. Sebanyak 15 pita protein ekstrak ikan tongkol yaitu protein dengan kisaran berat molekul antara 17-152 kDa.

Hasil yang berbeda didapatkan oleh Yamada dan Zychlinsky (1999). Hal ini diperkirakan karena tongkol berasal dari spesies, sumber atau laut tempat ikan tongkol ditangkap serta metode ekstraksi protein. Berat molekul protein ikan tongkol albacore dan ikan tongkol (T. albacares) dari laut Amerika lebih dominan didapatkan pada molekul 52 sampai $188 \mathrm{kDda}$ pada tongkol albacore dibandingkan dengan yellowfin dan bahkan protein dengan berat molekul 21 dan $46 \mathrm{kDa}$ 
pada ikan tongkol spesies yellowfin tidak ditemukan pada tongkol $T$. alalunga dan $\mathrm{T}$. albacares. Protein ikan tongkol species $T$. obesus dan $T$. thynnus yang diekstrak denga bufer tris- $\mathrm{HCl} \mathrm{pH} 2$ dan dikarakterisasi dengan elektroforesis menghasilkan pita protein dengan berat molekul 25 sampai 180 $\mathrm{kDa}$, (Pepe et al., 2012).

Tabel 1. Hasil analisis berat molekul ekstrak protein ikan tongkol*

\begin{tabular}{clccc}
\hline \multirow{2}{*}{ No } & \multicolumn{2}{c}{ Protein Marker } & \multicolumn{2}{c}{ Protein Tongkol } \\
\cline { 2 - 5 } & Jenis Protein & BM & Pita & BM (kDa) \\
\hline 1 & BSA & 116 & 1 & 152 \\
2 & Ovalbumin & 66 & 2 & 135 \\
3 & Lactate & 45 & 3 & 97 \\
& Dehydrogenase & & & \\
4 & RNase Bsp981 & 35 & 4 & 78 \\
5 & B galaktoglobulin & 25 & 5 & 59 \\
6 & Lysozyme & 18 & 6 & 49 \\
7 & BSA & 14 & 7 & 45 \\
8 & & & 8 & 34 \\
9 & & & 9 & 27 \\
10 & & & 10 & 24 \\
11 & & & 11 & 22 \\
12 & & & 12 & 21 \\
13 & & & 14 & 19 \\
14 & & & 15 & 17 \\
15 & &
\end{tabular}

$\mathrm{BM}=$ berat molekul, $*$ hasil analisis dengan software gelAnalyzer

Tabel 2. Hasil analisis kadar air, protein reagen ikan tongkol untuk SPT

\begin{tabular}{|c|c|c|}
\hline Parameter & $\begin{array}{l}\text { Reagaen } \\
\text { Ikan } \\
\text { Tongkol }\end{array}$ & $\begin{array}{l}\text { European } \\
\text { Pharmacopoeia } \\
\text { (2010:1063 }\end{array}$ \\
\hline $\begin{array}{l}\text { Kadar air } \\
(\%)\end{array}$ & $62.55 \pm 0.08^{*}$ & $\begin{array}{l}\text { Maksimum } 5 \% \\
\text { untuk produk } \\
\text { hasil freeze-dried } \\
\text { dan dapat lebih } \\
\text { dari } 5 \% \text { untuk } \\
\text { produk cair }\end{array}$ \\
\hline $\begin{array}{l}\text { Kadar } \\
\text { Protein } \\
(\mu \mathrm{g} / \mathrm{mL})\end{array}$ & $1.0^{\#}$ & $\begin{array}{lr}80-120 \% & \text { dari } \\
\text { kadar } & \text { yang } \\
\text { dinyatakan } & \end{array}$ \\
\hline
\end{tabular}

Pengolahan juga berpengaruh terhadap profil protein ikan tongkol seperti yang didapatkan oleh Misnan et al., (2005) dimana sebanyak 26 pita protein dengan berat molekul antara 11 sampai $175 \mathrm{kDa}$ pada ikan tongkol mentah sedangkan jumlah pita protein yang muncul untuk tongkol yang dimasak lebih sedikit.

\section{Komposisi Kimia Reagen SPT}

Reagen SPT merupakan sediaan farmasi dan harus steril, mengandung alergen mayor dan minor. Sediaan reagen SPT disiapkan dengan gliserol $50 \%$ (v/v) dan fenol $0.4 \%$ sebagai pengawet dan anti mikroorganisme (European Pharmacopenia 01/2005:1063). Hasil analisis kadar air dan kadar protein reagen SPT ikan tongkol ditampilkan pada Tabel 2.

European

Pharmacopoeia (2010:1063) menyatakan bahwa kadar air untuk produk produk cair atau larutan diperbolehkan lebih dari 5\%. Kadar air reagen ekstrak protein ikan tongkol didapatkan sebesar $62.55 \pm 0.08 \%$, nilai ini memenuhi kriteria farmakope Eropa.

Reagen SPT ikan tongkol disiapkan dalam bentuk glycerinated extract yaitu ekstrak dibuat dengan cara melarutkan ekstrak protein ikan tongkol dengan 50\% gliserolsaline mengandung $0.4 \%$ fenol sehingga konsentrasi akhir produk menjadi $1 \mu \mathrm{g} / \mu \mathrm{L}$. Fenol berfungsi sebagai pengawet dan gliserol sebagai stabilizer (Gier et al., 2007). Penggunaan gliserol dan fenol juga dilakukan oleh Lizaso et al., (2006) yaitu membuat reagen SPT dari jamur Alternaria alternata dengan larutan $50 \%$ gliserol dalam saline $(\mathrm{NaCl})$ dan fenol $0.4 \%$.

Kadar protein reagen alergen menurut farmakope Eropa adalah $80-120 \%$ dari konsentrasi yang dinyatakan. Maksud angka 80-120\% adalah bila reagen disimpan dalam jangka waktu yang tertentu, saat digunakan uji SPT terhadap responden atau penderita alergi maka konsentrasi reagen dalam range yang ditetapkan. Konsentrasi ekstrak protein ikan tongkol didapatkan sebesar $25.72 \mu \mathrm{g} / \mu \mathrm{L}$ dan diencerkan secara bertingkat sehingga didapatkan $3.00 \mu \mathrm{g} / \mu \mathrm{L}$ dan diencerkan lagi sehingga didapatkan konsentrasi $1 \mu \mathrm{g} / \mu \mathrm{L}$.

\section{Hasil Sterilisasi Reagaen SPT}

Reagen SPT harus diuji sterilitas, walaupun produksi reagen SPT dilakukan secara steril. Uji sterilitas mengikuti prosedur Farmakope Indonesia edisi IV tahun 1995 yaitu ekstrak protein ikan tongkol dituangkan pada media yang mengandung tryptic soy agar (TSA), diinkubasi selama 2 hari pada suhu $37{ }^{\circ} \mathrm{C}$ kemudian diamati pertumbuhan bakteri. 
Produksi reagen SPT dikerjakan secara steril namun harus dilakukan uji konfirmasi sterilitas dengan metode total plate count (TPC) menggunakan media selektif terhadap $P$. aeruginosa dan $S$. aureus. Uji konfirmasi memberikan kepastian bahwa larutan yang digunakan untuk SPT bebas dari mikroorganisme penghasil nanah yaitu $P$ aerugionosa dan $S$. Aureus karena SPT sedikit melukai kulit, Hasil uji konfirmasi sterilitas reagen SPT ikan tongkol ditampilkan pada Tabel 3.

Tabel 3. Hasil uji konfirmasi sterilitas reagen SPT

\begin{tabular}{cllll}
\hline \multirow{2}{*}{ No } & \multicolumn{1}{c}{ Bahan } & \multicolumn{3}{c}{ Bakteri } \\
\cline { 3 - 4 } & & P. aeruginosa & S. aureus & Keterangan \\
\hline 1 & Ekstrak ikan tongkol & Tidak tumbuh & Tidak tumbuh & Steril \\
2 & Reagan SPT & Tidak tumbuh & Tidak tumbuh & Steril \\
3 & European Pharmacopoeia 7 & Tidak tumbuh dalam & Tidak tumbuh \\
& $\begin{array}{l}\text { 01/2011:50104. untuk rute penggunaan } \\
\text { melalui kulit }\end{array}$ & 1 g atau 1 mL & dalam 1g atau \\
\end{tabular}

European Pharmacopoeia 7 01/2011:50104

Tabel 4. Ukuran diameter bentol pada kulit responden terhadap reagen SPT ikan tongkol

\begin{tabular}{ccccc}
\hline Kode resp & $\begin{array}{c}\text { Diameter bentol } \\
\text { kontrol negatif }(\mathbf{m m})\end{array}$ & $\begin{array}{c}\text { Diameter bentol } \\
\text { kontrol positif (mm) }\end{array}$ & $\begin{array}{c}\text { Diameter bentol } \\
\text { reagen ikan tongkol } \\
(\mathbf{m m})\end{array}$ & Hasil SPT \\
\hline 01 & 2 & 5 & 7 & +4 \\
02 & 3 & 5 & 5 & +3 \\
03 & 4 & 5 & 5 & +3 \\
04 & 4 & 6 & 5 & +1 \\
05 & 3 & 6 & 4 & +1 \\
06 & 3 & 5 & 7 & +4 \\
07 & 3 & 5 & 6 & +4 \\
08 & 3 & 5 & 5 & +3 \\
09 & 3 & 6 & 5 & +2 \\
10 & 4 & 4 & 5 & +4 \\
11 & 3 & 4 & 4 & +3 \\
12 & 1 & 5 & 2 & 0 \\
13 & 2 & 5 & 2 & 0 \\
14 & 2 & 4 & 2 & 0 \\
16 & 3 & 5 & 2 & 0 \\
\hline
\end{tabular}

Resp $=$ respoden

\section{Hasil Skin Prick Test}

Nilai diameter bentol menunjukkan sensitivitas responden terhadap alergen yang dicukitkan. Hasil SPT ekstrak protein ikan tongkol ditampilkan pada Tabel 4. Reponden dinyatakan positif terhadap reagen SPT ikan tongkol dengan nilai ukuran diameter bentol antara 5 sampai $7 \mathrm{~mm}$. Responden 01, 06, 07 dan 10 terbukti sensitif terhadap reagen ikan tongkol dengan nilai SPT +4 . Nilai ini merupakan nilai paling tinggi untuk SPT reagen ikan tongkol namun bukan menunjukkan tingkat keparahan gejala klinis alergi ikan tongkol. Menurut Ta et al., (2011) menyatakan bahwa tidak ada korelasi positif antara tingkat keparahan gejala klinis dengan nilai SPT. Penderita alergi berat yang mengalami reaksi anafilaksis terhadap alergen inhalasi padahal diameter bentol hanya $3 \mathrm{~mm}$ pada SPT, hal sebaliknya terjadi pada penderita alergi makanan dimana ukuran diameter bentol lebih besar dari $10 \mathrm{~mm}$ dan hanya mengalami reaksi alergi yang ringan (Sporik dan Hosking, 2000).

Sebanyak 17 responden menyatakan dirinya menderita alergi kacang-kacangan (kuisioner), namun pada SPT terbukti hnayak 11 orang dinyatakan positif terhadap reagen 
ikan tongkol. Hal ini diperkirakan adanya reaktivitas silang (cross-reativity) antara alergen ikan tongkol dengan alergen kacangkacangan yaitu terdapat kemiripian atau homologi asam amino penyusun alergen ikan tongkol dengan alergen kacang-kacangan.

Menurut Lopata dan Lehrer (2010) reaksi silang terjadi karena kesamaan urutan asam amino pada alergen. Skuens asam amino alergen udang mempunyai kesamaan dengan epitop alergen Pen a1 tungau, kecoa dan tropomiosin lobster (Ayuso et al., 2001). Lack et al., (2003) menyatakan bahwa sensitasi alergen makanan terjadi melalui mukosa usus, pemakaian minyak kacang tanah pada kulit, partikel makanan di udara atau melalui reaktivitas silang dengan serbuk sari tanaman dan tungau melalui mukosa saluran pernafasan.

\section{Sensitivitas dan Spesifitas Reagen Ikan Tongkol}

Sensitivitas dan spesifitas reagen untuk SPT ditentukan dari analisis IgE total dan IgE spesifik responden positif alergi ikan tongkol dan responden non alergi ikan tongkol. Nilai IgE total dan $\operatorname{IgE}$ spesifik ditentukan dengan teknik Enzyme-linked immunosorbent assay (ELISA).

Konsentrasi $\operatorname{IgE}$ total dan IgE spesifik sebanding dengan absorbansi yang terukur oleh ELISA reader, dinyatakan sebagai perbandingan antara absorbansi serum responden alergi terhadap kontrol negative (Kumar et al., 2010). Hasil pengukuran $\operatorname{IgE}$ total dan IgE spesifik disajikan pada Tabel 5.

Nilai positif dinyatakan apabila nilai absorbansi serum responden alergi lebih besar dari absorbansi kontrol negatif ditambah dua kali standar deviasi (standard deviation) dan apabila absorban serum responden lebih kecil dari absorbansi kontrol negatif ditambah dua kali standar deviasi dinyatakan negatif (Kumar et al., 2010).

Pengolahan data IgE, IgE spesifik dan hasil SPT menghasilkan sebagai nilai sensitivitas dan spesifitas reagen ikan tongkal yaitu sebesar $81.8 \%$ untuk sensitivitas dan $100 \%$ untuk nila spesifitas. Nilai sensitivitas reagen ikan tongkol pada penelitian ini cukup tinggi. Sensitivitas menunjukkan jumlah orang yang benar-benar sakit pada kelompok responden yang menyatakan dirinya sakit dan juga diindentifikasi sebagai orang sakit dengan alat deteksi.
Tabel 5. Hasil analisis IgE total, IgE spesifik dan SPT pada responden alergi ikan tongkol dan nonalergi

\begin{tabular}{lccc}
\hline $\begin{array}{l}\text { Kode } \\
\text { Responden }\end{array}$ & $\begin{array}{c}\text { IgE } \\
\text { Total }\end{array}$ & $\begin{array}{c}\text { Reagen Ikan Tongkol } \\
\text { IgE spesifik }\end{array}$ & SPT \\
\hline 01 & + & + & + \\
02 & + & + & + \\
03 & + & + & + \\
04 & + & + & + \\
05 & + & + & + \\
06 & + & + & + \\
07 & + & - & + \\
08 & + & - & + \\
09 & + & + & + \\
10 & + & - & + \\
11 & + & - & + \\
12 & + & - & - \\
13 & + & + & - \\
14 & + & - & - \\
15 & + & + & - \\
16 & + & - & - \\
17 & + & - & - \\
Jumlah & & & \\
positif & $17(0)$ & $9(8)$ & $11(6)$ \\
(negatif) & & & \\
\hline
\end{tabular}

Tabel 6. Berat molekul pita protein alergen reagen ikan tongkol

\begin{tabular}{lcccc}
\hline \multirow{2}{*}{ Responden } & \multicolumn{4}{c}{$\begin{array}{c}\text { Berat molekul pita protein } \\
\text { alergen }\end{array}$} \\
\cline { 2 - 5 } & \multicolumn{5}{c}{$\begin{array}{c}\text { reagen ikan tongkol } \\
\text { (kDa) ke- }\end{array}$} \\
\cline { 2 - 5 } & $\mathbf{1}$ & $\mathbf{2}$ & $\mathbf{3}$ & $\mathbf{4}$ \\
\hline 01 & 26 & 23 & 14 & - \\
02 & 43 & 26 & 13 & - \\
03 & 25 & - & - & - \\
04 & 42 & 25 & 12 & - \\
05 & 25 & 12 & - & - \\
06 & 43 & 32 & 28 & 12 \\
07 & 43 & 27 & 12 & - \\
08 & 50 & 29 & - & - \\
09 & 43 & 25 & - & - \\
10 & 34 & 25 & 12 & - \\
\hline
\end{tabular}

Disimpulkan bahwa reagen SPT yang dibuat dari ikan tongkol perairan laut Indonesia sensitif dan spesifik untuk digunakan sebagai reagen SPT. Onesimo et al., (2013) menyatakan bahwa reagen yang dibuat dari susu segar lebih sensitif dibandingkan dengan reagen komersial. Thalayasingam et al., (2015) menyatakan bahwa sensitivitas dan spesifitas reagen SPT udang lokal Singapore didapatkan sebesar $82 \%$ dan $22.2 \%$. Hal yang sama juga didapatkan oleh Chalid et al (2015) yaitu 
reagen udang jerbung yang digunakan pada SPT mempunyai nilai sensitivitas sebesar $95 \%$ dengan nilai spesifitas sebesar $94 \%$.

\section{Protein Alergen}

Sebanyak 9 serum responden positif bereaksi dengan alergen ikan tongkol yaitu muncul pita berwarna coklat. Berat molekul pita coklat dianalisis menggunakan software Gel Analyzer 2010a. Hasil immunoblotting ditampilkan pada Gambar 3.

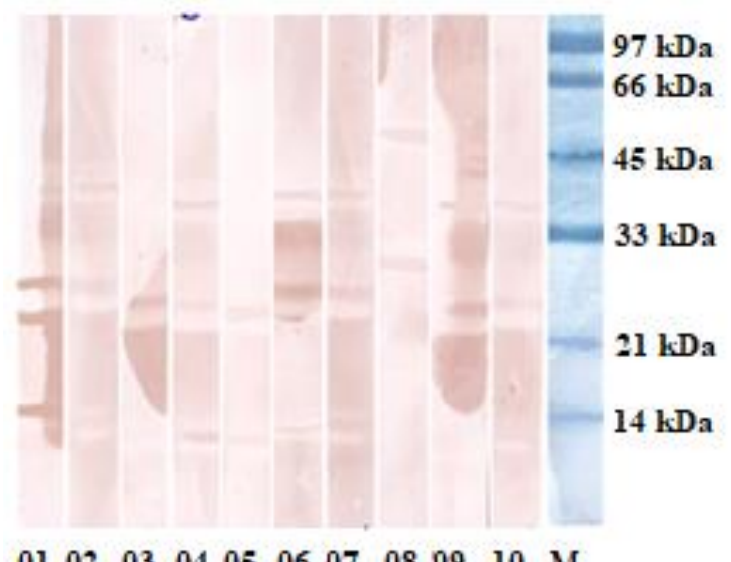

$\begin{array}{lllllllllll}01 & 02 & 03 & 04 & 05 & 06 & 07 & 08 & 09 & 10 & M\end{array}$

Gambar 3. Hasil immunoblotting ekstrak protein ikan tongkol dengan serum responden positif SPT, $M$ adalah protein marker

Sebanyak sepuluh serum responden dinyatakan positif yaitu berikatan dengan protein alergen ikan tongkol, ini menandakan bahwa ekstrak protein ikan tongkol mengandung protein alergen. Hasil perhitungan berat molekul alergen ditampilkan pada Tabel 6.

Protein yang positif dengan serum responden adalah protein dengan berat molekul berkisar antara 12 sampai $50 \mathrm{kDa}$. Molekul protein dengan berat molekul $25 \mathrm{kDa}$ bersifat alergen pada responden 03, 04, 05, 09 dan 10, sedangkan protein dengan berat molekul 26 $\mathrm{kDa}$ bersifat allergen yang positif dengan serum responden 01 dan 02. Hal ini menunjukkan bahwa setiap IgE serum responden berikatan dengan protein yang berbeda-beda.

Alergen utama pada ikan tongkol adalah parvalbumin yaitu protein dengan berat molekul 9-11 $\mathrm{kDa}$ dan tropomyosin pada krustasea dan moluska (Fernandeset et al., 2015). Misnan et al. (2005) menemukan protein alergen mayor pada ikan tongkol perairan Malaysia adalah protein dengan berat molekul antara 42 dan $50 \mathrm{kDa}$. Menurut Das Dores (2002) alergen aldehyde phosphate dehydrogenase dengan berat molekul $41 \mathrm{kDa}$ merupakan alergen ikan laut selain parvalbumin

Berdasarkan uraian di atas, besar kemungkinan protein alergen yang terdapat pada ikan tongkol ( $T$. albacares) bukan parvalbumin. Identifikasi protein alergen secara tepat dan pasti disarankan untuk dilakukan menggunakan skuensing asam amino atau protein crystallography.

\section{SIMPULAN}

Berdasarkan hasil penelitian dapat disimpulkan bahwa ikan tongkol dari perairan Indonesia dapat digunakan sebagai reagen SPT untuk mendeteksi alergi ikan tongkol. Sebanyak 15 pita protein terdeteksi pada ekstrak protein ikan tongkol yaitu protein dengan berat molekul antara 17 sampai 152 kDa. Protein alergen pada ekstrak protein ikan tongkol mempunyai berat molekul 12 sampai $50 \mathrm{kDa}$ dan reagen SPT ikan tongkol mempunyai sensitivitas yang tinggi.

\section{UCAPAN TERIMA KASIH}

Ucapan terima kasih disampaikan kepada Rektor UIN Syarif Hidayatullah Jakarta atas bantuan dana penelitian. Ucapan terima kasih juga disampaikan kepada Balai Besar Penelitian Veteriner Bogor yang telah membantu penelitian ini dengan fasilitas laboratorium Parasitologi

\section{DAFTAR PUSTAKA}

Aberoumand A. 2012. Proximate composition of less known some processed and fresh fish species for determination of the nutritive values in Iran. J. Agri. Tech. 8(3): 917922.

Ayuso R, Reese G, Leong-Kee S, Plante M, Lehrer SB. 2002. Molecular basis of arthropod cross-reactivity: IgE-binding cross-reactive epitopes of shrimp, house dust mite and cockroach tropomyosins. International archives of allergy and immunology. 129(1): 38-48.

Baratawidjaja KG. 1991. Penyakit Alergi, Tantangan dan Harapan. Majalah Kedokteran Indonesia. 41: 7.

Benjakul S, Seymour TA, Morrissey MT, AN, H. 
1997. Physicochemical changes in Pacific whiting muscle proteins during iced storage. Journal of Food science. 62(4): 729-733.

Bindslev-Jensen C, Ballmer-Weber BK., Bengtsson U, Blanco C, Ebner C, Hourihane J, Osterballe M. 2004. Standardization of food challenges in patients with immediate reactions to foods-position paper from the European Academy of Allergology and Clinical Immunology. Allergy. 59(7): 690697.

Bollag DM, and Edelstein SJ. 1991. Protein Method. New York (USA): Willey-Liss.

Bradford M. 1976. A Rapid and sensitive method for the quantitation of microgram quantities of protein utilizing the principle of protein-dye binding. Anal Biochem. 72(1-2): 248-54.

Brian M, Jarvis D, Burney P, Cullinan P, Jones M. 2017. S102 Identification of allergens present in drosophila melanogaster using a serum immunoblotting method. Thorax. 72(3): A62.

Cianferoni, Antonella, Jonathan MS. 2009. Food allergy: review, classification and diagnosis. allergology international. Official $J$ the Japanese Society of Allergology 58(4): 457-66.

Canoy, Dexter. 2015. A Dictionary of Epidemiology, 6th edition. Oxford(UK): Oxford University Press Editor: Miguel Porta. BBA Clinical. 4. 42-43.

Chalid, SY, Syah D, Giriwono PE, Zakaria FR. 2017. Pengembangan ekstrak protein udang jerbung (penaeus merquiensis) lokal indonesia sebagai reagent uji alergi dengan metode skin prick test (SPT). J Ilmu Kefarmasian Indonesia. 13(2): 205-215.

Candra Y, Setiarini A, RengganisI. 2011. Gambaran sensitivitas terhadap alergen makanan. Makara Kesehatan. 15(1): 4450 .

Cynthia MS, Malcolm NB. 2008. Allergens and Allergen Immunotherapy: Definition of An Allergen (Immunobiology). Minnesota(USA): University of Minnesota Minneapolis.

Departemen Kesehatan Republik Indonesia. Farmakope Indonesia Edisi IV. Direktorat
Jendral Pengawasan Obat dan Makanan 1995.

Diaz-Tenorio LM, Fernando L, Garcia-Carreno, Pacheco-aguil AR. 2007. Comparison of freezing and thawing treatmen on muscle properties of whieleg shrimph (litopenaeus Vannamei). J Food Biochemistry 31(2): 563-576.

Das Dores S, Chopin C, Villaume C, Fleurence J, Gueant JL. 2002. IgE-binding and crossreactivity of a new $41 \mathrm{kDa}$ allergen of codfish. Allergy. 57(72): 79-83.

Durham SR, Church MK. 2006. Principles of allergy. China Mosby Elsevier. hlm 4-16.

Engbaek K, Heuck C, Moody AH. 2003. Manual of basic techniques for a health laboratory. World Health Organization.

European Directorate for the Quality of Medicines (EDQM). 2010. Monograph: Allergen Products-Producta Allergenica 01/2010: 1063. Council of Europe (ed.) European Pharmacopoeia. 6: 679-680.

Er B, Demirhan B, Bas SY, Yentur G, Oktem AB. 2014. Determination of histamine levels in canned tuna fish. Bulgarian Journal of Agricultural Science. 20(4): 834-838.

Food Drug Adminstration.1996. Decomposition and histamine in raw, frozen tuna and mahi-mahi, canned tuna, and related species. Compliance Policy Guides 7108.240. Section 540-525.

Fernandes TJ, Costa J, Oliveira MBP, Mafra I. 2015. An overview on fish and shellfish allergens and current methods of detection. Food and Agricultural Immunology. 26(6): 848-869.

Grier TJ, LeFevre DM, Duncan EA, Esch RE. 2007. Stability of standardized grass, dust mite, cat, and short ragweed allergens after mixing with mold or cockroach extracts. Annals of Allergy, Asthma \& Immunology. 99(2): 151-160.

Hansen KS, Bindslev-Jensen C, Skov PS, Sparholt SH, Hansen GN, Niemeijer NR, Poulsen LK. 2001. Standardization of food allergen extracts for skin prick test. Journal of Chromatography B: Biomedical Sciences and Applications. 756(1-2): 57-69.

Hashimoto K, Watabe S, Kono M, Shiro K. 1979. 
Muscle protein composition of sardine and mackerel. B Jpn Soc Sci Fish. 45(11):1435-1441.

Heinzerling L, Mari A, Bergmann KC, Bresciani M, Burbach G, Darsow U, Bom AT. 2013. The skin prick test-European standards. Clinical and translational allergy. 3(1): 3.

Kay AB. 2001. Allergy and Allergic Diseases. N. Engl. J. Med. 344, 30-37.

Kianifar HR, Pourreza A, Azad FJ, Yousefzadeh H, Masomi F. 2016. Sensitivity comparison of the skin prick test and serum and fecal radio allergosorbent test (RAST) in diagnosis of food allergy in children. Reports of biochemistry \& molecular biology. 4(2): 98.

Kindt TJ, Goldsby RA, Osborne BA, Kuby J. 2007. Kuby immunology. Macmillan.

Kulis M, Wright BL, Jones SM, Burks AW. 2015. Diagnosis, management, and investigational therapies for food allergies. Gastroenterology. 148(6): 11321142 .

Kumar R, Kumari D, Srivastava P, Khare V, Fakhr H, Arora N. Gaur SN, Singh BP. 2010. Identification of IgE-mediated food allergy and allergens in older children and adults with asthma and allergic rhinitis. Indian $J$ Chest Dis Allied Sci. 52(4): 217-224.

Lack G, Fox D, Northstone $\mathrm{K}$ and Golding J. 2003. Factors Associated with the Development of Peanut Allergy in Childhood. The New England J Medicine. 348 (11): 977-85.

Lazer I, GelAnalyzer LI. 2010. Freeware 1D gel electrophoresis image analysis software. 2010. (http:// gelanalyzer.com/).

Lopata A, Lehrer S. 2009. Seafood Allergen Overview: Focus on Crustace. Jędrychowski L, Wichers HJ, editor. Chemical and Biological Properties of Food Allergens. CRC Press. United States of America.

Lizaso MT, Martínez JA, Asturias J, Algorta B, Madariaga, Labarta NA, Tabar I, Gárate AM. 2006. Biological standardization and maximum tolerated dose estimation of an alternaria alternata allergenic extract. Journal of Investigational Allergology and Clinical Immunology. 16(2): 94-103.
Lubis A, Barlianto W, Endaryanto A, Harsono A. 2017. Compatibility of clinical manifestation with skin prick test result and food provocation test in food cross reaction. Berkala Ilmu Kesehatan Kulit dan Kelamin. 29(2): 106-116.

Maleki SJ, Casillas AM, Kaza U, Wilson BA, Nesbit JB, Reimoneqnue C, Bahna SL. 2010. Differences among heat-treated, raw, and commercial peanut extracts by skin testing and immunoblotting. Annals of allergy, asthma \& immunology. 105(6): 451-457.

Misnan R, Murad S, Arif M, Abdullah N \& Mohamed J. 2005. Characterization of immunoglobulin E-binding proteins ( $\operatorname{IgE}$ ) of Scomberomorus commerson Lacepede. J Sains Kesihatan Malaysia. 3(2) 79-87.

Nurmatov U, Dhami S, Arasi S, Pajno GB, Fernandez-Rivas M, Murray A, Bindslev-Jensen C. 2017. Allergen immunotherapy for IgE-mediated food allergy: a systematic review andmeta-analysis. Allergy. 72(8): 11331147.

Onesimo R, Monaco S, Greco M, Caffarelli C, Calvani M, Tripodi S, Sopo SM. 2013. Predictive value of MP4 (Milk Prick Four), a panel of skin prick test for the diagnosis of pediatric immediate cow's milk allergy. Eur Ann Allergy ClinImmunol. 45(6): 201-8.

Pepe T, Ceruso M, Carpentieri A, Ventrone I, Amoresano A, Anastasio A and Cortesi ML. 2012. Differentiation of four tuna species by two-dimensional electrophoresis and mass spectrometric analysis. InTech. Open Access Publisher. 192- 208.

Rabson A, Roitt IM, Delves PJ. 2005. Really Essential Medical Immunology. Blackwell Publishing: 148-163.

Sampson HA. 1988. Comparative study of commercial food antigen extracts for the diagnosis of food hypersensitivity. Journal of allergy and clinical immunology. 82(5): 718-726.

Sampson HA, Van WRG, Bindslev-Jensen C, Sicherer S, Teuber SS, Burks AW, Dubois AE, Beyer K, Eigenmann PA, Spergel JM, Werfel T, Chinchilli VM. 2012. Standardizing double-blind, placebo- 
controlled oral food challenges: American Academy of Allergy, Asthma \& Immunology-European Academy of Allergy and Clinical Immunology PRACTALL consensus report. Journal of Allergy and Clinical Immunology. 130(6): 1260-1274.

Sporik R, Hill DJ, Hosking CS. 2000. Specificity of allergen skin testing in predicting positive open food challenges to milk, egg and peanut in children. Clin Exp Allergy. 30(11): 1540-6.

Ta V, Weldon B, Yu G, Humblet O, Neale-May S, Nadeau K. 2011. Use of specific IgE and skin prick test to determine clinical reaction severity. British Journal of Medicine and Medical Research. 1(4): 410-429.

Taylor SL, Stratton JE, Nordlee JA. 1989. Histamine poisoning (scombroid fish poisoning): an allergy-like intoxication. Journal of Toxicology: Clinical Toxicology. 27(4-5): 225-240.

Thalayasingam M, Gerez IFA, Yap GC, Llanora GV, Chia IP, Chua L, Tang CY. 2015.
Clinical and immunochemical profiles of food challenge proven or anaphylactic shrimp allergy in tropical $S$ ingapore. Clinical \& Experimental Allergy. 45(3): 687-697.

Valenta R, Hochwallner H, Linhart B, Pahr S. 2015. Food allergies: the basics. Gastroenterology. 148(6): $\quad 1120$ 1131.

Verstege A, Mehl A, Rolinck-Werninghaus C, Staden U, Nocon M, Beyer K, Niggemann B. 2005. The predictive value of the skin prick test weal size for the outcome of oral food challenges. Clinical \& Experimental Allergy. 35(9): 1220-1226.

Vlieg P, Murray T. 1988. Proximate composition of albacore tuna, Thunnus alalunga, from the temperate South Pacific and Tasman Sea. New Zealand Journal of Marine and Freshwater Research. 22(4): 491-496.

Yamada S, Zychlinsky E. 1999. Identifying allergens in fish. Di dalam Bremner HA, editor. Safety and Quality Issues in Fish Processing. CRC Press. Copenhagen. 